\title{
Microshoots encapsulation and plant conversion of Musa sp. cv. 'Grand Naine’
}

\author{
Encapsulamento de microbrotos e conversão em plantas de Musa sp. cultivar 'Grand Naine'
}

\author{
Edgar Wilfredo Sandoval-Yugar ${ }^{\mathrm{I}}$ Lírio Luiz Dal Vesco ${ }^{\mathrm{I}}$ Douglas André Steinmacher ${ }^{\mathrm{I}}$ \\ Elaine Cristina Stolf ${ }^{\mathrm{I}}$ Miguel Pedro Guerra ${ }^{\mathrm{I}^{*}}$
}

\begin{abstract}
Synthetic seed technologies are useful tools for the field delivery of in vitro derived plantlets. In the present study, different encapsulation procedures and their efficacy in the plantlet regeneration using microshoots of banana cv. 'Grand Naine' were evaluated. Two encapsulation systems were evaluated: i) single encapsulation in beads or droplet hardening method; and ii) double layer or hollow beads. The use of different compounds to enhance the capsule conservation and the conversion to plantlets was also evaluated. The conversion capacity was assessed in vitro on water-agar culture medium or in ex vitro conditions with Gerbox ${ }^{\circledR}$ boxes. The single encapsulation system showed $80 \%$ conversion. The capsules with MS saline formulation treated with $100 \mathrm{mM} \mathrm{KNO}_{3}$ showed $76 \%$ conversion. Capsules with $1.5 \mathrm{~g} \mathrm{~L}^{-1}$ activated charcoal, and $0.5 \mathrm{~g} \mathrm{~L}^{-1}$ benomyl sucrose-free capsules showed $75 \%$ conversion. The encapsulated and non-encapsulated microshoots exhibited $100 \%$ germination in response to MS culture medium, and polyethylene glycol after 10 days of storage at $4^{\circ} \mathrm{C}$. Sucrose-free capsules showed significantly higher germination (83.3\%) than those sucrose-enriched capsules (56.7\%). The ex vitro conversion of encapsulated microshoots was $20 \%$ in the Gerbox ${ }^{\mathrm{TM}}$. These results indicate the feasibility using synthetic seeds in the large-scale micropropagation of banana cv. 'Grand Naine'.
\end{abstract}

Key words: artificial seeds, banana, in vitro propagation, pharmaceutical capsules.

\section{RESUMO}

As tecnologias de semente sintética são ferramentas promissoras para a micropropagação de plantas. O objetivo do presente trabalho foi desenvolver um protocolo de encapsulamento e armazenamento de unidades encapsuláveis a partir de microbrotos de bananeira da cultivar 'Grand

\begin{abstract}
Naine'. Foram avaliados dois sistemas de encapsulamento: i) formação de cápsula pelo método de camada simples e ii) camada dupla. Foi avaliada também a adição de diferentes adjuvantes na matriz de alginato para promover a conservação da cápsula e favorecer a conversão em plantas. Para a conversão em planta foram avaliadas as condições in vitro sobre o meio de cultura composto de agar-água e as condições ex vitro em caixas Gerbox ${ }^{\circledR}$. O melhor sistema de encapsulamento para os microbrotos da bananeira da cultivar 'Grand Naine' foi o de camada simples, com 80\% de conversão. O emprego da formulação salina MS na forma de endosperma artificial e a descomplexação com $100 \mathrm{mM} \mathrm{KNO}_{3}$ favoreceram a conversão de microbrotos (76\%). A adição de carvão ativado $\left(1,5 g L^{-1}\right)$ e de benomyl $\left(0.5 g L^{-1}\right)$, na ausência de sacarose na matriz de alginato, resultou em $75 \%$ de conversão, além de reduzir a oxidação e a contaminação dos microbrotos. Microbrotos encapsulados e não-encapsulados revelaram $100 \%$ de germinação em resposta ao meio de cultura MS e PEG após 10 dias de estocagem a $4^{\circ} \mathrm{C}$. Cápsulas sem a adição de sacarose resultaram em 83,3\% de conversão, valor superior ao valor obtido com a adição de sacarose $(56,7 \%)$. A conversão de microbrotos encapsulados foi de $20 \%$ nas condições ex vitro. Os resultados indicam a viabilidade de uso destas tecnologias para a micropropagação em larga escala da cultivar de banana 'Grand Naine'.
\end{abstract}

Palavras-chave: banana, semente sintética, propagação in vitro, cápsula farmacêutica.

\section{INTRODUCTION}

Synthetic seeds consist of artificially encapsulated somatic propagules (embryos, shoots or other in vitro-derived propagule) capable of conversion

'Programa de Pós-graduação em Recursos Genéticos Vegetais, Universidade Federal de Santa Catarina (UFSC), 88040-900, Florianópolis, SC, Brasil. E-mail: mpguerra@cca.ufsc.br. *Autor para correspondência. 
into plantlets in vitro or ex vitro conditions (AITKENCHRISTIE et al., 1995). Encapsulated technology using in vitro-grown propagules offers an efficient means for mass clonal propagation and conservation of elite or endangered plant species (MALLÓN et al., 2007). The main advantages using synthetic seed techniques are associated with the elimination of the final micropropagation stages (i.e. rooting and acclimatization) allowing direct delivery as well as the development of cost-effective propagation systems (SINGH et al., 2006). Nevertheless, to reach such objective, the encapsulation technique must be firstly improved regarding its composition and conditions for short term storage.

In the case of banana (Musa sp), the use of synthetic seed techniques may improve the quality of the plantlets, and decreasing the production costs. This technique was successfully employed in the cvs. 'Basrai' by GANAPATHI et al. (1992), 'Nanicão' by MATSUMOTO et al. (1995) and 'Rasthali' by GANAPATHI et al. (2001) and resulting in high conversion rates (100\%, 75\% and 66\%, respectively). However, in all these cases only in vitro conversion was tested on sucrose and/or plant growth regulatorsenriched culture medium.

The general methodologies for the production of synthetic seeds using sodium alginate were described by REDENBAUGH et al. (1993), following by the development of the technique using pharmaceutical capsules (DUPUIS et al., 1994). Later, it was proposed the double layer or hollow beads techniques based upon production of capsules with a gelled external layer surrounding a liquid internal layer (PATEL et al., 2000). Thus, the first step towards the development of an efficient and reliable protocol for the production of synthetic seeds is the correct choice of the encapsulation methodology, associated with the composition of the matrix.

The synthetic seed technology application in commercial scale is still hampered by the low efficiency of the protocols and logistic behind it. For instance, the conversion step should be already accomplished in ex vitro conditions or very simple in vitro conditions, making the logistic process easier without requiring specialized facilities for their conversion. To the best of our knowledge, up to now in the systems developed for banana synthetic seeds only in vitro conversion was evaluated. The direct transference of the synthetic seeds to ex vitro conditions was already successfully described in bromeliads (RECH FILHO, 2004). Therefore, an optimized system using synthetic seeds should include the best conversion rate of these, feasibility to short- term storage regarding logistic and ex vitro conversion or on simplified conditions.

The objective of this study was to evaluate different encapsulation systems, short-term storability and incorporation of co-adjuvant (fungicide and activated charcoal), as well as the regeneration capacity of synthetic seeds containing microshoots of banana cv. 'Grand Naine’.

\section{MATERIAL AND METHODS}

Apical buds (3mm) of banana cv. 'Grand Naine' were excised and inoculated in $200 \mathrm{~mL}$ glass flasks containing $30 \mathrm{~mL}$ of culture medium with the following composition: MS saline formulation (MURASHIGE \& SKOOG, 1962) supplemented with 6benzylaminopurine (BAP) $(4.4 \mu \mathrm{M})$, sucrose $\left(30 \mathrm{~g} \mathrm{~L}^{-1}\right)$ and gelled with agar Merse ${ }^{\circledR}\left(7.5 \mathrm{~g} \mathrm{~L}^{-1}\right)$. The $\mathrm{pH}$ of the culture medium was adjusted to 5.8 prior adding the gelling agent and autoclaved at $1.5 \mathrm{kgf} \mathrm{cm}^{-2}$ at $121^{\circ} \mathrm{C}$ for $15 \mathrm{~min}$. After 30 days, the cultures were transferred to $300 \mathrm{~mL}$ glass flasks containing $20 \mathrm{~mL}$ of MS liquid culture medium supplemented with $44.4 \mu \mathrm{M}$ of BAP and subcultured at six week intervals. At the end of the fourth subculture, microshoots here defined as clusters of unipolar axis 6-8mm in length were obtained and subjected to a fast dehydration ( $5 \mathrm{~min}$ ) in flow chamber over sterile paper filter, being subsequently used for the encapsulation procedures. The sodium alginate, the starch and the pharmaceutical capsules were sterilized under UV light during 30min. The MS saline formulation incorporated into the matrix gel had the $\mathrm{pH}$ adjusted to 5.8, then autoclaved at $1.5 \mathrm{kgf} \mathrm{cm}^{-2} 121^{\circ} \mathrm{C}$ for $15 \mathrm{~min}$ before ionotropic gelation.

Microshoots of 6-8mm were used as explant source for obtaining synthetic seeds. Different encapsulation systems were evaluated: i) single encapsulation in beads or droplet hardening method (REDENBAUGH et al., 1993) consisting of MS salts plus $1 \%(\mathrm{w} / \mathrm{v})$ sodium alginate which was dropped into $100 \mathrm{mM} \mathrm{CaCl} \mathrm{m}_{2}$ solution for 20min for hardening; ii) double layer or hollow beads, adapted from PATEL et al. (2000), with the carboxymethylcelulose replaced by $5 \%$ starch in a $\mathrm{CaCl}_{2} 100 \mathrm{mM}$ solution for $20 \mathrm{~min}$. The resulting capsule was then immersed in a solution of $1 \%$ sodium alginate, then drooped in a $\mathrm{CaCl}_{2}$ solution and hardened for 20min; and, iii) pharmaceutical capsules (DUPUIS et al., 1994) filled with liquid MS salts and the microshoots. Thereafter synthetic seeds for procedure 1 and 2 were subjected to $100 \mathrm{mM} \mathrm{KNO}_{3}$ for $20 \mathrm{~min}$. In the procedure 2 (hollow beads) the carboxymethylcelulose was replaced by $5 \%$ starch for being readily available, biocompatible, cost-effective 
and presenting adequate viscosity. The conversion percentage was recorded after 4 weeks in 300mL glass flasks containing $40 \mathrm{~mL}$ of MS culture medium gelled with agar Merse ${ }^{\circledR}\left(7.5 \mathrm{~g} \mathrm{~L}^{-1}\right)$.

Based on the results obtained new experiments were carried out to improve shoot emergence of encapsulated microshoots. Each microshoot was included in alginate solution and then dropped into $\mathrm{CaCl}_{2} 100 \mathrm{mM}$. The beads formed by ionotropic gelation were hardened in the same solution for $20 \mathrm{~min}$.

The in vitro conversion of the capsules was analyzed to evaluate the effects of such components in the shoot emergence of the microshoots. Firstly, it was evaluated the effect of the presence or absence of MS salts (factor A) in the sodium alginate matrix and the presence or absence of a $\mathrm{KNO}_{3}$ treatment (Factor B). The capsules were immersed in $100 \mathrm{mM} \mathrm{KNO}_{3}$ for $20 \mathrm{~min}$ as proposed by ONISHI et al. (1994). Such treatment replaces the calcium by potassium in the alginate matrix. Distilled water was used in the control treatment. Secondly, it was evaluated the effect of activated charcoal ( 0.0 or $1.5 \mathrm{~g} \mathrm{~L}^{-1}$, Factor A), benomyl (0.0; 0.5 or $1.0 \mathrm{~g} \mathrm{~L}^{-1}-$ Benlate $^{\mathrm{TM}}$, DuPont Co., Factor B), and the MS salts in the alginate matrix as co-adjuvant. Finally, it was evaluated the tolerance of the microshoots to low temperatures in response to different osmoprotectors as follow: 1) MS; 2) MS + DMSO - dimethyl sulfoxide (10\% w/v); 3) MS + DMSO 20\%; 4) MS + polyethylene glycol (PEG) (FW 8000) $10 \%$, and 5) MS + PEG-8000 20\%. The encapsulated and non-encapsulated microshoots were then coldhardened at $4^{\circ} \mathrm{C}$ for 10 days in the dark. The encapsulated microshoots were incubated in sterile Petri dishes and sealed with Parafilm ${ }^{\circledR}$. The nonencapsulated microshoots were placed in Petri dishes containing the culture medium supplemented with the osmoprotector treatments, gelled with agar Merse ${ }^{\circledR}$ (7.5 $\left.\mathrm{g} \mathrm{L}^{-1}\right)$. After the short-term storage (10 days) the synthetic seeds were subjected to $\mathrm{KNO}_{3} 100 \mathrm{mM}$ for $20 \mathrm{~min}$. The synthetic seeds of the three experiments were then inoculated in flasks $(300 \mathrm{~mL})$ containing $40 \mathrm{~mL}$ water-Agar (7.5g L $\mathrm{g}^{-1}-$ Merse $\left.^{\circledR}\right)$ to evaluate their shoot emergence percentage and data were recorded after 4 weeks in culture.

The optimized conditions described above were used to evaluate the effect of sucrose ( 0 and $30 \mathrm{~g}$ $\mathrm{L}^{-1}$ ) in the matrix solution was also evaluated and the shoot emergence percentage was measured both in in vitro and ex vitro conditions. The synthetic seeds were aseptically transferred to in vitro conditions for their conversion in flasks $(300 \mathrm{~mL})$ containing $40 \mathrm{~mL}$ water gelled with Agar (7.5g L ${ }^{-1}$ - Merse ${ }^{\circledR}$ ) and autoclaved for
$15 \mathrm{~min}$ at $121^{\circ} \mathrm{C}\left(1.5 \mathrm{kgf} \mathrm{cm}^{-2}\right.$.) or in standard Gerbox ${ }^{\circledR}$ boxes with filter paper moistened with distilled water and benomyl $1.0 \mathrm{~g} \mathrm{~L}^{-1}$. All the cultures were maintained in a culture room at $25 \pm 2^{\circ} \mathrm{C}$ under $16 \mathrm{~h}$ light with an intensity of $50-70 \mu \mathrm{mol} \mathrm{m} \mathrm{m}^{-2} \mathrm{~s}^{-1}$ provided by cool-white fluorescent (Sylvania) and high pressure sodium vapor lamps (Empalux-VST).

The experiments were carried in a randomized block design, with four repetitions of 10 synthetic seeds. Data of shoot emergence percentage were scored until stabilization or after four weeks in culture.Data were subjected to analysis of variance (ANOVA) and means separation using SNK at 0.05 level using Statgraphics software, version 7.0.

\section{RESULTS}

The ionotropic gelation of sodium alginate by $\mathrm{Ca}^{2+}$ ions was an efficient procedure for the production of synthetic seeds of banana (Figure 1a). The systems of single layer and double layer showed $80 \%$ and $70 \%$ conversion, respectively, without statistical differences between these treatments (Table 1). A significant low conversion percentage (15\%) was observed using pharmaceutical capsules. Leakage of culture medium was often observed using pharmaceutical gelatin capsules, which in turn drastically reduced the conversion percentage.

The highest (76\%) shoot emergence was obtained in the treatment with $\mathrm{KNO}_{3}$ and MS (Table 2). The conversion occurred after two weeks in culture (Figure 1b). The lowest shoot emergence rate (32\%) was observed in the capsules without $\mathrm{MS}$ and $\mathrm{KNO}_{3}$ (Table 2).

The incorporation of a fungicide to avoid contaminants is an appropriate strategy to increase shoot emergence or conversion of synthetic seeds. In the present study, in vitro microshoot emergence capacity was influenced by the interaction between activated charcoal and the fungicide benomyl. Shoot emergence increased significantly $(\mathrm{P} \leq 0.05)$ to $75.0 \%$ in the presence of $1.5 \mathrm{~g} \mathrm{~L}^{-1}$ activated charcoal and $0.5 \mathrm{~g} \mathrm{~L}^{-1}$ benomyl (Table 3). However, the use of fungicide alone in the matrix (i.e. without charcoal) negatively affected the microshoots conversion (36.2\%) to plantlets. Additionally, activated charcoal reduced the browning of microshoots and enhanced the plantlets vigor (Figure 1c).

The encapsulated and non-encapsulated microshoots showed $100 \%$ shoot emergence in response to treatments with MS solely or in combination with PEG (10\% and $20 \%$ ), after a shortterm storage at $4^{\circ} \mathrm{C}$ for 10 days. In the treatment with 


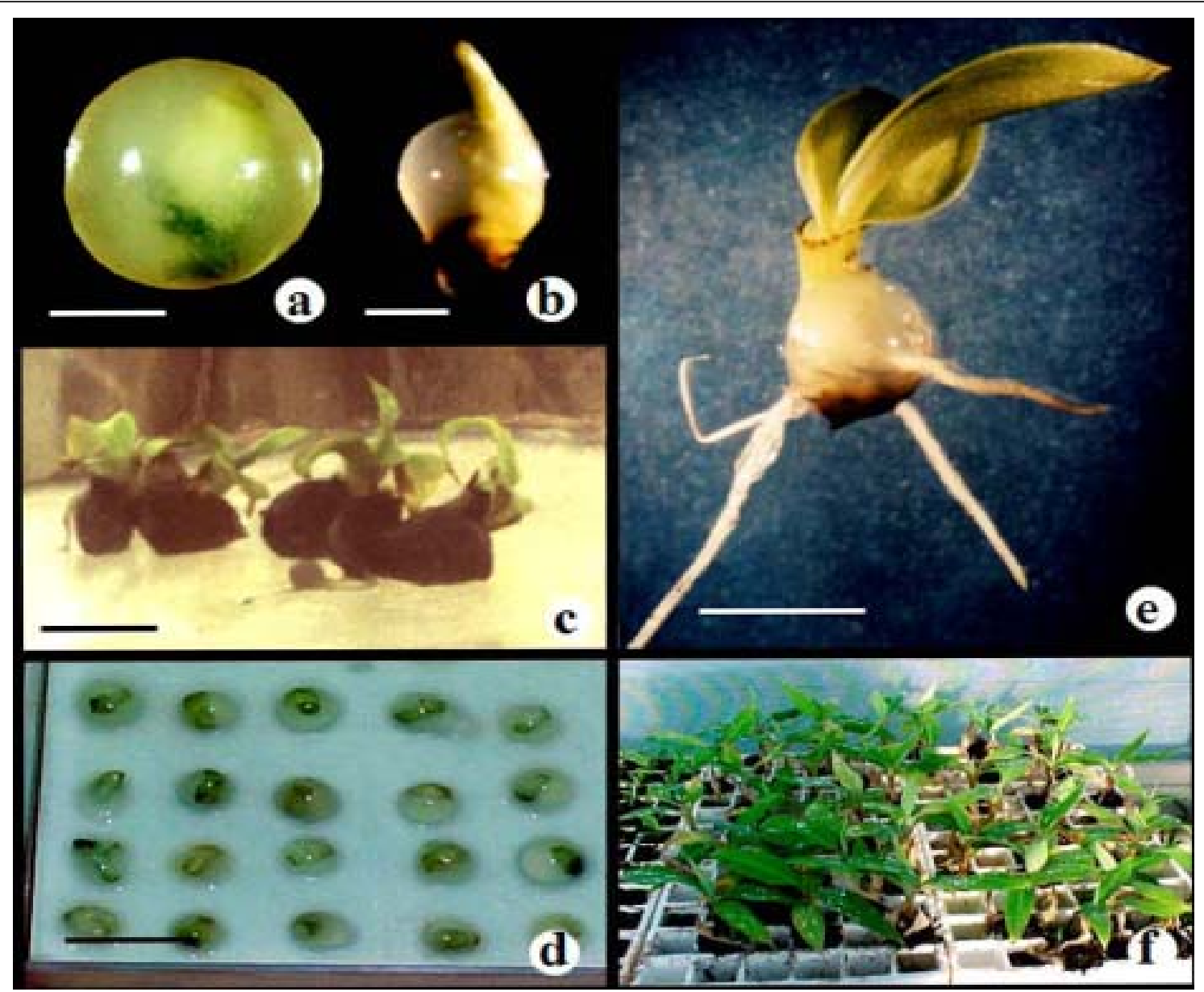

Figure 1 - Encapsulated microshoots of banana Grand Naine. a) Encapsulated microshoot in double layer system $($ Bar $=5 \mathrm{~mm})$. b) Conversion of microshoot $(\mathrm{Bar}=3 \mathrm{~mm})$. c) Close-up of the converted microshoot $(\mathrm{Bar}=1 \mathrm{~cm})$. d) Ex vitro conversion of microshoot in $\operatorname{Gerbox}^{\circledast}(\mathrm{Bar}=3 \mathrm{~cm})$. e) In vitro regrowth in plantlets $(\mathrm{Bar}=2 \mathrm{~cm})$. f) Plantlets derived from encapsulated microshoots. CCA/UFSC, 2005.

$10 \%$ DMSO, the encapsulated and non-encapsulated microshoots showed viability of 90 and $60 \%$ respectively. The use of $20 \%$ DMSO resulted in $20 \%$ viability in encapsulated microshoots. No conversion of the non-encapsulated microshoots was observed

Table 1 - Conversion rate of banana cv. Grand Naine microshoots in response to different encapsulating techniques. CCA/UFSC, 2005.

\begin{tabular}{lc}
\hline Technique & Conversion rate $(\%)^{1}$ \\
\hline Single layer & $80.0 \mathrm{a}$ \\
Double layer & $70.0 \mathrm{a}$ \\
Pharmaceutical capsules & $15.0 \mathrm{~b}$ \\
Mean & 55.0 \\
CV $(\%)$ & 14.8 \\
\hline
\end{tabular}

${ }^{1}$ Treatments followed by the same letter are not different (SNK test at $\mathrm{P}=0.05$ ). and this may be due to DMSO toxicity (data not shown).

Since the presence of sucrose may affect the further growth of the capsules, the presence or absence of sucrose in the capsule was tested. Sucrosefree capsules showed high $(\mathrm{P} \leq 0.01)$ in vitro shoot emergence (83.3\%) compared to those containing $30 \mathrm{~g}$ $\mathrm{l}^{-1}$ sucrose $(56.7 \%)$. Sucrose-free synthetic seeds cultivated in Gerbox ${ }^{\circledR}$ boxes (Figure 1d) had 20\% conversion. On the other hand, all the capsules containing sucrose got contaminated (data not shown). Sucrose-free capsules did not contaminate and enhanced the quality of the converted plantlets (Figure 1e).

In the present study, the microshoots encapsulated in sucrose-free capsules had a high potential to convert into plantlets on culture medium containing only agar and water (Figure 1c). These 
Table 2 - Conversion rate (\%) of banana cv. 'Grand Naine' microshoots in response to MS saline formulation (MURASHIGE \& SKOOG, 1962) culture mediumenriched matrix and self-breaking with $\mathrm{KNO}_{3}$ CCA/UFSC, 2005.

\begin{tabular}{lll}
\hline MS & $\mathrm{KNO}_{3}$ & \\
\hline Absence & 0 & Conversion rate (\%) \\
Absence & 100 & $32.0 \mathrm{~b}$ \\
Presence & 0 & $56.0 \mathrm{a}$ \\
Presence & 100 & $68.0 \mathrm{a}$ \\
Mean & & $76.0 \mathrm{a}$ \\
CV (\%) & & 58.0 \\
\hline
\end{tabular}

${ }^{1}$ Treatments followed by the same letter are not different (SNK test at $\mathrm{P}=0.05$ ).

plantlets were successfully acclimatized, and after 13 weeks $90 \%$ survival was observed (Figure 1f). Therefore, different strategies may be used regarding the germination of the encapsulated microshoots (i.e. direct transfer to ex vitro conditions or in vitro conditions with only water-agar culture medium).

\section{DISCUSSION}

Synthetic seeds are useful strategies for the field delivery of in vitro-grown propagules, and different systems for the encapsulation have been developed, including the encapsulation with calcium alginate or the use of pharmaceutical capsules. The system of single encapsulation based on sodium alginate beads hardened in $\mathrm{CaCl}_{2}$ was developed by REDENBAUGH et al. (1993), and subsequently it described the system

Table 3 - Conversion rate (\%) of banana cv. 'Grand Naine' microshoots in response to activated charcoal and benomyl supplemented to the alginate matrix. CCA/UFSC, 2005.

\begin{tabular}{|c|c|c|}
\hline & Treatments & \multirow[b]{2}{*}{ Conversion rate $(\%)^{1}$} \\
\hline $\begin{array}{l}\text { Benomyl } \\
\left(\mathrm{g} \mathrm{L}^{-1}\right)\end{array}$ & Activated charcoal $\left(\mathrm{g} \mathrm{L}^{-1}\right)$ & \\
\hline 0.0 & 0.0 & $58.5 b$ \\
\hline 0.5 & 0.0 & $52.7 b c$ \\
\hline 1.0 & 0.0 & $36.2 \mathrm{c}$ \\
\hline 0.0 & 1.5 & $52.5 b c$ \\
\hline 0.5 & 1.5 & $75.0 \mathrm{a}$ \\
\hline 1.0 & 1.5 & $56.5 b$ \\
\hline Mean & & 55.2 \\
\hline CV (\%) & & 17.4 \\
\hline
\end{tabular}

${ }^{1}$ Treatments followed by the same letter are not different (SNK test at $\mathrm{P}=0.05$ ). of hollow beads or double layer based on the ionotropic gellification of the calcium alginate (PATEL et al., 2000). In the present study, no difference was observed between the two encapsulation techniques using calcium alginate (single and double layer). The technique of pharmaceutical capsules resulted in low conversion rate since the microshoots were not able to disrupt the synthetic layer of the gelatin capsule or severe leaking of medium was observed. In contrast, carrot somatic embryos were successfully encapsulated using this technique and resulted in $90 \%$ conversion (DUPUIS et al., 1994).

It has been shown that the nutrients to be included in the alginate matrix should be adapted according to propagule type and plant species (NAIK \& CHAND, 2006; SINGH et al., 2006). However, the complex composition of endosperm makes difficult its reconstitution and the use of standard culture medium in the capsule may increase the conversion of the propagule to plantlets (MAMIYA \& SAKAMOTO, 2000). This is in agreement with our results, where the addition of MS in the alginate matrix together with $\mathrm{KNO}_{3}$ treatment increased the microshoots conversion, however there were no differences with the treatment without MS but there were with the $\mathrm{KNO}_{3}$ treatment. These results show that capsule weakening through $\mathrm{KNO}_{3}$ treatment results in high conversion capacity of the shoots, which is improved by an additional nutrient supply.

Fungicides and antibiotics have beneficial effects against contamination of the synthetic seeds in several species, including banana (GANAPATHI et al., 1992). Similarly, in pineapple the use of antibiotics in the matrix capsule resulted in $86.1 \%$ conversion of microshoots (GANGOPADHYAY et al., 2005). In the present work the presence of benomyl $\left(1 \mathrm{~g} \mathrm{~L}^{-1}\right)$ alone negatively affected the viability of the encapsulated microshoots. However, the use of a lower concentration $\left(0.5 \mathrm{~g} \mathrm{~L}^{-1}\right)$ combined with activated charcoal significantly increased the conversion of the microshoots. The incorporation of a fungicide in the capsule to eradicate contaminants without harming the cultures was also an appropriate strategy for the micropropagation of Hibiscus moscheutos (WEST \& PREECE, 2006).

An interesting strategy for the delivery of synthetic seeds involves their storage (NAIK \& CHAND, 2006). In the present study, no dehydration was necessary for the short-term storage (10 days at $4^{\circ} \mathrm{C}$ ) and the microshoots showed $100 \%$ shoot emergence in response to the treatments containing MS solely or in combination with PEG (10\% and 20\%). Treatments employing DMSO actually reduced the shoot emergence.

Ciência Rural, v.39, n.4, jul, 2009. 
The contamination of the synthetic seeds was low in the absence of sucrose and the synthetic seeds also showed higher in vitro conversion capacity when compared to sucrose-enriched gelling matrix. In contrast, it was showed (MATSUMOTO et al., 1995) that encapsulated banana shoot tips were able to grow only in the presence of sucrose in the culture medium or in the capsules. Probably in the absence of sucrose the microshoots were forced to undergo photosynthesis. It is well known that a regulative feedback occurs in response to the presence of sugars and the photosynthetic capacity of the plants, as shown in banana (NGUYEN \& KOZAI, 2001). The conversion of encapsulated somatic embryos of asparagus showed an inverse correlation among the levels of sucrose in the capsule and the fresh weight of the plantlets (MAMIYA \& SAKAMOTO, 2000). In Kiwi, however, the addition of sucrose to the conversion medium enhanced the conversion to plantlets of microcuttings encapsulated in a calcium-sodium alginate solution (ADRIANI et al., 2000).

In summary, the protocol for the production of banana synthetic seeds of microshoots includes the use of alginate capsules containing sucrose-free MS salts, activated charcoal $\left(1.5 \mathrm{~g} \mathrm{~L}^{-1}\right)$ and benomyl $(0.5 \mathrm{~g}$ $\mathrm{L}^{-1}$ ), and $\mathrm{KNO}_{3}$ solution $(100 \mathrm{mM})$ treatment for $20 \mathrm{~min}$ for weakening of the capsules. The synthetic seeds showed high survival rate after short-term (10 days) storage, where no special treatments were required. The encapsulation system tested with banana microshoots without any sucrose and plant growth regulators enables direct delivery of the in vitro propagules without any in vitro rooting step. The main advantage over other technologies developed for banana microshoots refers to the use of sugar-free capsules and the ex vitro growth using Gerbox ${ }^{\circledR}$ with moistened paper or the in vitro conversion on a very simple culture medium, containing only gelled water. Therefore, this new technology has direct impact on the delivery of the in vitro propagules with suitable costs.

\section{ACKNOWLEDGEMENTS}

The authors gratefully acknowledge the financial support of Coordenação de Aperfeiçoamento de Pessoal de Nível Superior (CAPES), Conselho Nacional de Desenvolvimento Científico e Tecnológico (CNPq) for grants and fellowships. We also thank EPAGRI - E.E. Itajaí for supplying plant material.

\section{REFERENCES}

ADRIANI, M. et al. Effect of different treatments on the conversion of 'Hayward' kiwifruir synthetic seeds to whole plants following encapsulation of in vitro-derived buds. New Zealand J. of Crop and Horticultural Science, v.28, p.5967, 2000.

AITKEn-CHRistie, J. et al. Automation and environmental control in plant tissue culture. Dordrecht: Kluwer Academic Publishers, 1995. 574p.

DUPUIS, J-M. et al. Pharmaceutical capsules as a coating system for artificial seeds. Bio/Technology, v.12, p.385-389, 1994. Disponível em: http://www.nature.com/nbt/journal/v12/ n4/abs/nbt0494-385.html. Doi: 10.1038/nbt0494-385.

GANAPATHI, T. R. et al. Regeneration of plants from alginateencapsulated somatic embryos of banana cv. 'rasthali' (Musa spp. AAB group). In Vitro Cell Dev Biol -Plant, v.37, p.178181, 2001.

GANGOPADHYAY, G. et al. Encapsulation of pineapple micro shoots in alginate beads for temporary storage. Current Science, v.88, p.972-977, 2005.

MALLÓN, R. et al. Encapsulation of moss buds: an efficient method for the in vitro conservation and regeneration of the endangered moss Splachnum ampullaceum. Plant Cell Tissue Organ Culture, v.88, p.41-49, 2007. Disponível em: http:// www.springerlink.com/content/v0662686j787m084/. Doi: $10.1007 / \mathrm{s} 11240-006-9176-1$

MAMIYA, K.; SAKAMOTO, Y. Effects of sugar concentration and strength of basal medium on conversion of somatic embryos in Asparagus officinalis L. Scientia Horticulturae, v.84, p.15-26, 2000. Disponível em: http://www.sciencedirect.com/ science?_ob=ArticleURL\&_udi=B6TC3-3YNY77D$2 \&$ \&user $=687358 \&$ \&doc $=1 \&$ _fmt $=\&$ \&_orig $=$ search $\&$ _sort $=\mathrm{d} \&$ view $=$ c\&_acct $=C 000037899 \&$ \& version $=1 \& \_$_urlVersion $=0$ \&_userid $=68735$ 8\&md5=5ca58f92b02fbcd26964b0c5cc34d338. Doi: 10.1016/ S0304-4238(99)00098-9.

MATSUMOTO, K. et al. In vitro growth of encapsulated shoot tips in banana (Musa sp). Acta Horticulturae, v.370, p.1320, 1995.

MURASHIGE, T.; SKOOG, F. A revised medium for rapid growth and biossays with tobacco tissue cultures. Physiologia Plantarum, v.15, p.473-497, 1962.

NAIK, S.K.; CHAND, P.K. Nutrient-alginate encapsulation of in vitro nodal segments of pomegranate (Punica granatum L.) for germplasm distribution and exchange. Scientia Horticulturae, v.108, p.247-252, 2006. Disponível em: http://www.sciencedirect.com/ science?_ob=ArticleURL\&_udi=B6TC3-4JF97TK$2 \&$ _user $=687358 \& \_r d o c=1 \& \_\mathrm{fmt}=\&$ \& orig $=$ search $\& \_s o r t=\mathrm{d} \&$ view $=$ c\&_acct $=$ C000037899\&_version $=1 \&$ \&_urlVersion $=0 \&$ _userid=687358\&md5=9cfefc7fb80c1e7c2e0075de52d78fbc. Doi: 10.1016/j.scienta.2006.01.030.

NGUYEN, Q.T.; KOZAI, T. Growth of in vitro banana (Musa spp.) shoots under photomixotrophic and photoautotrophic conditions. In Vitro Cell Dev Biol -Plant, v.37, p. 824-829, 2001.

ONISHI, N. et al. Synthetic seeds as an application of mass production of somatic embryos. Plant Cell Tissue Organ Culture, v.39, p.137-145, 1994. Disponível em: http:// 
www.springerlink.com/content/p92376213845x6x3/. Doi: 10.1007/BF00033921.

PATEL, A.V. et al. A novel encapsulation technique for the production of artificial seeds. Plant Cell Reports, v.19, p.868874, 2000. Disponível em: http://www.springerlink.com/ content/3300t59ee1h93tuj/. Doi: 10.1007/s002990000223.

RECH FILHO, A. Biorreatores de imersão temporária e unidades encapsuláveis como ferramentas na consolidação de protocolos de micropropagação de bromélias. 2004. 74f. Dissertação (Mestrado em Recursos Genéticos Vegetais) - Curso de Pós-graduação em Recursos Genéticos Vegetais, Universidade Federal de Santa Catarina.

REDENBAUGH, K. et al. Hydrated coatings for synthetic seeds. In: REDENBAUGH, K. (Ed.), Synseeds: applications of synthetic seeds to crop improvement. Boca Raton: CRC, 1993. p.35-46.

SINGH, A.K. et al. Plant regeneration from alginateencapsulated shoot tips of Phyllanthus amarus Schum and Thonn, a medicinally important plant species. In Vitro Cell Dev Biol - Plant, v.42, p.109-113, 2006. Disponível em: http://www.springerlink.com/content/0375021333851724/. Doi: 10.1079/IVP2005735.

WEST, T.P.; PREECE, J.E. Use of Acephate, Benomyl and alginate encapsulation for eliminating culture mites and fungal contamination from in vitro cultures of hardy hibiscus (Hibiscus moscheutos L). In Vitro Cell Dev Biol - Plant, v.42, p.301304, 2006. Disponível em: http://www.springerlink.com/ content/h2842346q342823k/. Doi: 10.1079/IVP2006774. 